\title{
PROBLEM ETIK DALAM HUKUM POSITIF
}

\section{Oleh :}

\author{
Ari Purwadi \\ (e-mail: aripurwadi.fhuwks@yahoo.co.id) \\ Dosen DPK Kopertis Wilayah VII Di UWKS \\ JI. Dukuh Kupang XXXV/ 54 Surabaya 60225 Telp./Fax : (031) 5674186.
}

\begin{abstract}
Ethics refer to desirable conduct. Determining what is desirable conduct in a given situation depends on what values one follows. The value recommend to guide in positive law. Jurisprudence is the study of values concerning law and legal systems. Schools of jurisprudence present different values for judging whether positive law is appropriate ethical conduct.
\end{abstract}

Keywords : ethics, conduct, value, positive law, jurisprudence.

Tulisan ini didahului dengan 3 cerita sebagaimana yang ditulis oleh Fisher dan Phillips (Bruce D. Fisher dan Michael J. Phillips, 2001: 3-4):

Wilson Ford dipecat oleh majikannya, karena digagalkan suatu tes detektor kebohongan. Dia mengatakan telah menyimpan uang tunai milik majikannya, malam hari, pada Bank NCNB. Tetapi bank tidak menemukan deposito pada hari esoknya, maka majikannya menyatakan bahwa dia berbohong tentang menyimpan uang di bank tersebut, dengan cara suatu tes detektor kebohongan.

Perlukah suatu kekurangan pekerja dengan tes detektor kebohongan dapat layak dipercaya? Eric, tidak dibayar uang kontrak untuk membangun kolam renang untuk taman milik Dorothy Powell, meskipun kolam bekerja bagus. Dorothy menyatakan bahwa Eric tidak mempunyai lisensi pemborong (kontraktor) kolam renang, dan berdasarkan hukum menyatakan bahwa kontrakmu yang demikian itu adalah cacat. Eric berpikir ini adalah tidak dilarang dan orang sedang mempercayakan terlalu banyak pada hukum untuk menentukan apa yang benar (berhak) atau salah. Dorothy datang dan menawarkan pekerjaan, yang kemudian dilaksanakan oleh Eric dengan penawaran yang rendah.

Hukum lisensi tidak menyatakan Dorothy tidak boleh membayar kepada Eric. Menurut Eric, yaitu lakukan hal yang secara moral benar dengan membayar kepada Eric.

Ralph, pada waktu menjadi mahasiswa telah menulis surat ke anggota Konggres yang menuntut hukum pengendalian polusi yang kuat dan hukum perlindungan pekerja, mencakup suatu upah minimum pemerintah federal lebih 
tinggi dan hak pekerja untuk tawarmenawar secara bersama. la percaya bahwa semua tindakan ini akan berperan untuk keadilan. Juga, Ralph mencoba untuk memaksimalkan kegunaan ketika membelanjakan uangnya.

Waktunya ia masuk lapangan pekerjaan, ia telah diterima di perusahaan mobil Chrysler. Pada suatau kesempatan, ia diberi kesempatan ikut pada program pelatihan supervisor Chrysler, kemudia Ralph telah terpilih sebagai supervisor. Ralph dengan agresif mendorong Chrysler untuk memperkerjakan wanitawanita dan kelompok minoritas, untuk mematuhi hukum lingkungan, dan untuk mengadopsi dan menyelenggarakan perlindungan karyawan seperti yang diimpikan oleh UU Kesehatan dan Keselamatan Kerja.

Ketika gaji pertama diterima, Ralph memutuskan untuk membeli suatu mobil baru. la tidak mempertimbangkan mobil produk Chrysler tetapi memutuskan mobil Hyundai buatan Korea sebab lebih murah dan tentang mutu dapat diperbandingkan dengan mobil Chrysler sebagai sarana angkut.

Ketika ia mengemudi Hyundai itu untuk bekerja, beberapa teman sekerja bertanya kepada Ralph mengapa ia telah membawa mobil produk asing maka dia menjawab, bahwa kualitas dan harga karena mobil ini adalah lebih murah dan keandalan sama.

Namun,seorang teman sekerja mencatat bahwa negara Korea tidak mempunyai hukum upah minimum, hukum lingkungan, dan hak-hak karyawan dalam bentuk program tindakan yang harus dilakukan sebagaimana yang telah dihimbau oleh Ralph kepada Chrysler untuk mengikuti.

Dia menjawab, bahwa ia mempunyai suatu pendapatan terbatas dan harus membuat uang sejauh mungkin dengan pembelian barang-barang harga yang paling rendah di pasar. Itu tidak hanya berlaku bagi mobil, tetapi ke makanan, pakaian, dan semua selain itu. Apa yang etik menurut undang-undang dilibatkan skenario ini?.

Cerita tersebut membawa persoalan karena banyak berlawanan dengan gagasan mereka tentang perilaku yang layak (pantas). Menentukan perilaku yang layak (pantas) pada suatu situasi ditentukan oleh di sekitar apakah etik itu.

Tulisan ini akan mencoba memperkenalkan topik etik dengan cara berikut: a. Akan mendiskusikan secara umum atas kehadiran etik ini mengenai pengertian, sifat, dan batas-batas etik; b. bagaimana menjelaskan etik hukum positif; c. jurisprudence (dalam hal ini studi mengenai etik hukum) mendiskusikan dan merumuskan bersama dengan suatu diskusi ringkas berbagai kepercayaan 
yang diakui tentang nilai-nilai etis berhubungan dengan hukum.

\section{Pengertian, Sifat, dan Batas-Batas Etik}

Suatu pembedaan harus digambarkan antara etik dan moral. Etik adalah standard atau ukuran untuk perilaku manusia. Moral, pada sisi lain, berhubungan dengan praktek yang secara etis atau didukung oleh kebiasaan. Seperti itu, etik, sebagai Patterson menyatakan, " mengacu pada sistem norma-norma yang teoritis yang memandu perilaku manusia", dan moral menunjuk " kepada sikap dan praktek yang berlaku dalam masyarakat atau golongan masyarakat". Etika adalah diarahkan pada nilai, dan moral adalah dikaitkan dengan perilaku (Ervin $\mathrm{H}$. Pollack, 1979: 400).

Etik berkaitan dengan studi tentang perilaku mengenai hak, kebaikan, dan moral. Dikatakan juga, etik termasuk studi ketidakcocokan nilai-nilai moral. Dengan kata lain, keberadaan problem etik karena kita mempunyai pilihan. Sebagai contoh, perlukah seorang kaya menawarkan uang bagi seorang pengemis yang meminta-minta di jalan?

Orang kaya mungkin mempertimbangkan situasi dan menyimpulkan bahwa memberi suatu jumlah kecil adalah " sesuatu yang baik" sebab yang dilakukan sangat akan memungkinkan pengemis itu untuk membeli makanan dan dengan demikian untuk kelangsungan hidupnya. Pada sisi lain, orang kaya mungkin berpikir memberi uang ke pengemis akan mendorong untuk meminta saja daripada bekerja, yang merupakan sarana yang lebih baik memperoleh uang. Seperti itu, etik mengasumsikan seseorang mempunyai beberapa aneka pilihan di dalam suatu situasi. Kebanyakan situasi dilakukan, sesungguhnya, menawarkan beberapa aneka pilihan perilaku.

Contoh lain yang dipertimbangkan, seorang pelaku bisnis tidak ingin membayar pajak pendapatan. Dalam hal situasi sedemikian mungkin dikatakan bahwa pelaku bisnis tidak punya pilihan melainkan untuk membayar sebab dikehendaki hukum. Bagaimanapun, bisnis bisa berhenti untuk beroperasi; kemudian itu akan tidak berhutang pajak. Pilihan ini boleh nampak mustahil ketika kelangsungan hidup adalah suatu etik yang paling diakui, tetapi keputusan untuk melanjutkan bisnis adalah suatu pilihan. Pilihan lain adalah untuk dusta sekitar pendapatan seseorang, mengakui yang tidak ada pendapatan kena pajak. Di sini pilihan tersebut melibatkan pelanggaran hukum ( atau hukum positif) atau mematuhi itu. Studi etik tidak perlu berasumsi bahwa hukum yang positif harus dalam semua keadaan dipatuhi. 
Seringkali didengar kode etik untuk para akuntan, para pengacara, para dokter, para arsitek, para insinyur, dan lain profesi. Kode etik ini mencoba untuk menetapkan sebelumnya apa yang dikerjakan para profesional pada situasi yang melibatkan perselisihan nilai. Sebagai contoh, seorang akuntan boleh menghadapi suatu dilema etis ketika suatu klien meminta dengan tegas mengikuti suatu strategi pajak penuh resiko yang akuntan mengetahui akan ditanyakan oleh otoritas pajak. Suatu kode etik profesional boleh membantu ke arah bicara perihal ini.

Beberapa hal muncul dari studi etik. Pertama-tama, etik sifatnya nilai-nilai pokok. Ini menunjukan kita suatu nilai moral bagi sesuatu, sebab kita menghargai hal itu. Karena etik adalah nilai-nilai pokok, maka mereka mem-benarkan diri sendiri. Cara lain yang dikatakan, etik adalah suatu a priori, maksudnya bahwa mereka adalah diasumsikan berharga dengan tidak ada kebutuhan lebih lanjut untuk per-timbangan.

Jika seseorang men-gatakan keadilan adalah suatu etik atau nilai pokok, penjelasan lebih lanjut jarang diperlukan sebab kebanyakan orang siap memahami keinginan keadilan.

Etik atau nilai-nilai pokok kadangkadang konflik, dan satu etik dapat tetap membenarkan sisi berlawanan isu yang sama itu. Ketika konflik jenis ini terjadi, kita mempunyai kerancuan etik. Dalam cerita awal tulisan ini berisi kerancuan etik. Untuk contoh lain, memper-timbangkan suatu hukum yang mem-biarkan hukuman mati. Seorang yang percaya pada moral tentang keadilan mungkin membantah hukum hukuman mati itu, adalah tidak adil dan tidak sah sebab itu disebut pembunuhan dengan sengaja dengan mengambil hidup pembunuh itu. Pendukung hukuman mati, pada sisi lain, mungkin membantah bahwa keadilan dengan menuntut hukuman mati agar dihindari para pembunuh lainnya dan juga mengutip pandangaan dalil bahwa jika seseorang dicabut hidupnya, pembunuh menyerahkan hidupnya.

Siapakah yang berhak mengancam hukuman mati? Kedua sisi mempunyai argumentasi etis kuat. Argumentasi etis tidak perlu mengakibatkan satu jawaban benar. Karenanya, kita mempunyai apa yang disebut suatu " ethical ambiguity" atau dilema etis

Bagaimana cara kita memecahkan dilema etis? Kita membuat suatu keputusan. Kita melakukan sesuatu. Walaupun dilema etis boleh kadangkadang mengacaukan kita, terdapat nilainilai mereka dalam membantu kita membuat informasi keputusan. Kita membawa semua faktor relevan ke dalam tanggung jawab membuat keputusan kita. 
Juga, pengetahuan etis membuat kita lebih mengartikulasikan.

Semakin mengartikulasikan, kita membenarkan rancangan atau posisi, semakin kekuasaan kita memberi kepada posisi itu dan penerimaan potensi mereka yang lain.

Di dunia praktik, etik yang dapat memecahkan kerancuan untuk seharihari kita adalah hukum positif. Tulisan yang berikutnya akan menguji etik dari hukum positif.

\section{Etik dari Hukum Positif}

Aliran jurisprudence yang membahas lebih mendalam tentang hukum positif adalah legal positivism. Legal positivism bersama-sama dengan teori positivistis pada umumnya menolak spekulasi metafisis dan pencarian prinsipprinsip yang mendasar. Hukum menurut kaum positivis tidak lain dari pada hukum positif dan hukum positif adalah hukum yang dibuat oleh penguasa.

Ketika kebanyakan orang menggunakan kata hukum mereka sedang mengacu pada hukum positif. Orang Inggris bernama John Austin, yang dianggap sebagai pelopor legal positivism menulis pada abad XIX, dihargai dengan mengembangkan gagasan untuk hukum positif seperti kita ketahui hari ini. Austin berkata hukum positif itu terdiri dari tiga bagian: aturan; dari suatu kedudukan politis lebih tinggi kepada suatu kedudukan yang lebih rendah; dengan sanksi memaksakan jika aturan dilanggar (G.W. Paton, $1974: 6$ ).

John Stuart Mill menulis tentang Austin, bahwa "Tidak ada penulis yang kita ketahui telah lebih banyak kualitas diperlukan untuk memulai dan menertibkan pikiran lain dalam seni yang sulit mengenai pikiran yang tepat". Setelah mempelajari Hukum Romawi, Austin menyadari betapa tertibnya Hukum Romawi dan tidak teraturnya Hukum Inggris, ia membuat perbedaan yang tajam antara jurisprudence dan the science of ethics. Jurisprudence hanya berkaitan dengan hukum positif. Yuris akan berurusan dengan hukum sebagaimana adanya.

Pembuat undang-undang dan ahli filsafat etika harus berurusan dengan dengan hukum sebagaimana seharusnya. Menurut kaum positivis, hukum positif tidak ada kaitannya dengan hukum yang adil atau yang ideal.

Fungsi jurisprudence menurut Austin adalah mengungkapkan pengertian -pengertian dan prinsip-prinsip umum yang diabstraksikan dari sistem hukum positif. Hukum positif memiliki karakter esensial, yaitu imperatif sebab merupakan perintah penguasa yang dalam hal ini adalah parlemen di Inggris. Putusan hakim dan 
peraturan organ administrasi dengan mendapat delegasi kewenangan, semuanya merupakan hukum positif.

Apa yang disampaikan oleh John Austin, sebagai pelopor positivisme dalam ilmu hukum, mengenai pengertian hukum positif tidak lain membuktikan adanya pemisahan secara kaku antara hukum dan moral.

Hart mengidentifikasi 5 arti yang berbeda mengenai positivisme, yaitu: Pertama: anggapan bahwa hukum adalah perintah manusia; Kedua: anggapan bahwa di sini tidak perlu ada hubungan antara hukum dan moral atau hukum sebagai "adanya" dan "seharusnya"; Ketiga: anggapan bahwa analisis (atau studi tentang pengertian) mengenai konsep hukum adalah (1) mengejar manfaat dan (2) untuk membedakan dari penyelidikan historis ke dalam kasuskasus atau asal hukum, dari penyelidikan sosiologis ke dalam hubungan antara hukum dan fenomena sosial lainnya, dan dari kritik atau penilaian apakah dalam moral, bantuan sosial, fungsi atau cara lainnya; Keempat: anggapan bahwa suatu sistem hukum adalah suatu sistem logika tertutup yang mengoreksi keputusan hukum dapat disimpulkan oleh pengertian logis dari sebelum menetapkan aturan hukum tanpa memandang batuan sosial, kebijakan-kebijakan, standar moral; Kelima: anggapan bahwa pertimbangan moral tidak dapat dipertahankan atau yang dibentuk sebagai pernyataan fakta, dengan argumentasi masuk akal, bukti, atau alat bukti (Lord Lloyd of Hampstead and M.D.A. Freeman, 1985 ; 263).

Kasus yang berikut meng-hadirkan isu apakah hukum positif -diikuti ketika kepatuhan akan dapat dibantah menghasilkan suatu hasil tak adil. Tanyakan diri anda apakah hukum positif atau kewajaran (keadilan).

Kasus Rushing melawan Powell (Pengadilan tingkat banding Kalifornia).( Bruce D. Fisher dan Michael J. Phillips, $2001 ; 7-8)$.

\section{Latar-belakang Dan Fakta:}

Dorothy Powell menggaji Eric Rushing untuk membangun kolam renang untuk taman kereta rumah dengan \$ 5,107.40. Eric mempunyai lisensi kontraktor beton Kalifornia

Bagaimanapun, ia tidak mempunyai suatu lisensi kontraktor kolam renang Kalifornia. Hukum Kalifornia melarang orang melakukan pekerja bagi mereka yang tanpa lisensi. Junior Ray Anderson adalah seorang yang memiliki lisensi kontraktor kolam renang Kalifornia. Eric menggunakan Junior untuk mendapatkan lisensi kontraktor kolam renang, maka ia bisa membangun kolam Dorothy Powell. 
Eric dan Junior memperoleh suatu kerjasama lisensi kontraktor kolam renang di bawah nama "Stardust Pools". Sebab Junior telah mempunyai lisensi seperti itu, Pejabat Perijinan Kalifornia melepaskan hak Eric dari pengambilan perijinan lewat ujian perijinan atau mempertunjukkan kemampuan untuk menjadi pemborong kolam renang. Eric memberi peralatan Junior seharga $\$ 6,000$ untuk membantu dia mendapatkan lisensi, Junior tidak pernah benar-benar melakukan pekerjaan konstruksi kolam renang manapun dengan Eric.

Eric membangun kolam Dorothy Powell, tetapi Dorothy menolak untuk membayar. la menuntut bahwa Eric tidak mengikuti rencana. Eric menggugat Dorothy dengan wanprestasi. Dorothy dengan mempertahankan batahan bahwa Eric tidak mentaati Undang-Undang nama bisnis samaran California atau Hukum perijinan kontraktor California. Pengadilan menghadiahi Eric \$ 5,107.40 ( jumlah kontrak) ditambah \$198.73 untuk pengeluaran di luar kontrak. Dorothy naik banding.

Isu: Mungkinkah suatu ganti kerugian kepada kontraktor yang telah bekerja jika dia tidak mempunyai lisensi pemborong yang sesuai dan belum mentaati undang-undang nama samaran?

Keputusan: Seorang kontraktor mungkin tidak diberi ganti kerugian atas pekerjaannya jika dia tidak berlisensi. Hukum lisensi kontraktor adalah diharapkan untuk melindungi publik melawan ketidakjujuran dan ketidakcakapan dan menghalangi para pelanggar. Kontraktor yang tidak berlisensi tidak akan menagih kontrak sejumlah \$ $5,107.40$. Bagaimanapun, kontraktor akan dipulihkan dengan \$198.73 untuk pengeluaran yang bukan merupakan bagian dari kontrak.

Kontraktor (Eric) mentaati undangundang nama samaran oleh pengisian suatu sertifikat yang mempertunjukkan bahwa ia sedang melakukan bisnis sebagai suatu individu.

Pertanyaan-pertanyaan : Manakah yang berlaku dalam kasus Rushing melawan Powell, aturan yang tertulis (hukum positif) atau keadilan? Apakah itu tidak adil untuk seseorang seperti Nona Powell untuk membantu dirinya mengenai suatu aturan untuk perbuatan yang dimaafkan dari suatu hutang berhutang yang melanggar hukum ? Tetapi adalah debitur berhutang menurut hukum ? Jika tujuan dari hukum lisensi-salah satu aturan diisukan dalam Rushing melawan Powell adalah untuk melindungi publik untuk melawan ketidakjujuran dan ketidakcakapan, bagaimana Nona Powell yang dirugikan atau yang ditipu oleh ketidakcakapan? Bisakah berargumentasi bahwa 
Nona Powell, sebagai orang yang menurut hukum lisensi sedang dicoba untuk dilindungi, apakah pelanggar di dalam kejadian ini?

Hukum positif adalah suatu persoalan praktis, luas, dan tidak dapat ditahui. Pertimbangkan yang berikut: Suatu pengendara motor dari New York mengemudi ke Tennessee di mana ada hujan dan menubruk mobil lain. Polisi memberikan pengendara New York suatu tuntutan untuk mengemudi tanpa lampu besar pada suatu hujan badai.

Pengendara New York membantah bahwa dia tidak berpengetahuan tentang Hukum Lalu lintas Tennessee sebab itu hari terang, sehingga dia tidak punya alasan untuk mengenakan lampu besarnya. Ketidaktahuan hukum tiada maaf. Kita adalah bertanggung jawab untuk mematuhi hukum positif dari tiap yurisdiksi.

Kita dapat memahami mengapa ketidaktahuan tidak harus dipertahankan, sebab orang bisa secara harafiah meloloskan diri dengan pembunuhan dengan membantah ketidaktahuan hukum pembunuhan ketika didakwa membunuh pasangan seseorang.

Oleh karena itu ketidaktahuan bukanlah suatu yang dipertahankan dan orang diharapkan untuk mengetahui hukum positif sungguhpun sebagai pengetahuan persoalan praktis adalah tidak mungkin (Bruce D. Fisher dan Michael J. Phillips , 2001: 8).

Ketidak percayaan di masyarakat, maka untuk memastikan kebenaran, seseorang mungkin secara individu berpikir untuk menggunakan ke tes detektor kebohongan. Bagaimanapun, orang-orang dapat mengatakan kebenaran detektor kebohongan mengatakan bahwa mereka berbohong dan oleh karena itu terpercaya. Kasus yang berikut menggambarkan ketidak andalan detektor kebohongan sebagai ukuran kepercayaan (Bruce D. Fisher dan Michael J.Phillips, 2001: 9-10).

Kasus Ford melawan NCNB Corporation (Pengadilan banding Kalifornia Utara) (Bruce D. Fisher dan Michael J. Phillips, 2001: 9-10).

\section{Latar belakang Dan Fakta-fakta:}

Tanggal 19 Agustus 1987, Wilson Ford menggugat NCNB Corporation (sebuah bank) untuk memulihkan kerugian yang menurut dugaan orang diakibatkan oleh kegagalan bank, untuk sekitar dua tahun, $\$ 5,000.15$ bahwa Ford ditempatkan sebagai salah satu dari tergugat tempat penyimpanan bank malam hari untuk pemberi kerjanya A\&P. Satu-satunya teori tanggung gugat pada awalnya dituduhkan merupakan pelanggaran atas suatu penyimpanan khusus dalam hubungan dengan deposito. Pengadu menuduh 
bahwa kegagalan bank lalai untuk menyelidiki tempat penyimpanan dengan baik menyebabkan penggugat kehilangan pekerjaannya dan menderita kehilangan nafkah, penderitaan emosional yang berat, penghinaan, caci maki, dan olok-olok. Bank tidak mencari tempat penyimpanan yang hilang sebab tidak membongkar itu. Sebelum memecat Ford, A\&P menanyakan dia dan dikalahkan suatu tes polygraph atas permintaan toko itu.

Setelah test diduga sebagian dari jawabnya adalah menipu, A\&P mengakhiri ketenaga-kerjaan penggugat pada tanggal 9 Oktober 1984 dan demikian dinasehatkan bank beberapa hari kemudian.

Selama bulan pertama mengikuti pemecatannya dalam berusaha untuk memperoleh ketenagakerjaan di tempat lain Ford yang sesungguhnya menceritakan kepada calon pemberi kerja apa yang telah terjadi pada A\&P dan tidaklah disewa. Setelah ia menghentikan untuk mendaftar kembali kepada A\&P sebagai pemberi kerja terdahulu, ia dengan seketika memperoleh ketenaga-kerjaan pada upah minimum dan di dalam beberapa bulan sesudah itu berpendapatan lebih dari apa yang ia telah menerima di A\&P.

Sebelum kantong deposito telah hilang Ford menikmati suatu reputasi baik antar karyawan A\&P dan adalah ramah, membantu untuk mendukung ibu nya dan tiga adik laki-laki, dan mengganti dengan suatu mobil baru dengan rencana angsuran. Setelah ia dipecat menjadi mobil ditarik dan sulit tidur dan berat badan turun.

Ketika teman-temannya yang manapun meghindari dia atau diejeknya dengan menolak untuk berbagi uang "yang hilang" dengan mereka, ia telah dipermalukan dan tertekan dan akan duduk di ruang nya berjam-jam merasa ragu apa sudah terjadi kepada kantong deposito. Mobil baru nya telah dikuasai kembali ia tidak bisa membayar dan nilai kelayakan pinjam baik nya telah dirusak. Pada tanggal 19 Juni 1986 kira-kira 2 tahun kemudiankunci pada bank NCNB deposito malam telah dilayani untuk membetulkan penyalah gunaan konsumen lain pada tempat penyimpanan malam.

Teknisi layanan mendengar suatu kikisan bunyi pada tempat penyimpanan dan ketika me-mindahkan kepala tempat penyimpanan menemukan kantong deposito yang hilang tersbut. Manajer toko A\&P menawarkan Ford bekerja kembali, yang ditolak Ford.

Ford kemudian menggugat NCNB untuk kegagalan yang lalai untuk menyelidiki dengan baik tempat penyimpanan. Suatu dewan juri menemukan kealpaan NCNB yang merugikan Ford dalam jumlah $\$ 100,000$, dan pertimbangan 
dimasukkan untuk bahwa jumlah itu oleh NCNB mohon naik banding.

Issue: Apakah kealpaan NCNB penyebab yang terdekat atau yang dekat A\&P memecat Ford?

Keputusan: Ya, ketika bank melaporkan bahwa tidak menerima deposito itu, ini menyebabkan A\&P untuk mencurigai Ford. NCNB menyebabkan A\&P untuk menyelidiki, mengurus tes polygraph (tes deteksi kebohongan), dan Ford dipecat ketika ia gagal tes. Dengan begitu NCNB tindakan dengan ceroboh menyelidiki dan tidak menemukan kantong itu yang kenyataannya di sana, menggerakkan peristiwa itu yang mengarahkan tes polygraph. Dengan begitu kealpaan NCNB adalah penyebab yang terdekat atau yang dekat pemecatan Ford.

Pertanyaan-pertanyaan: Apakah di sana ada bukti bahwa Ford berbohong? Apakah mungkin telah dilaksanakan untuk menghindari masalah dengan adanya kasus Ford?

\section{Jurisprudence Dan Nilai-nilai Etik Yang Berhubungan Dengan Hukum}

Penyelidikan untuk perilaku yang layak atau etik ditunjukkan banyak jawaban sebagai tambahan pandangan bahwa hukum positif menentukan apakah hak. Tulisan berikut mengamati pendapat dan menawarkan beberapa nilai-nilai baik untuk mendorong maupun tantangan bagi hukum positif untuk supremasi etik.

$$
\text { Jurisprudence merupakan suatu }
$$
wilayah studi menguji nilai-nilai atau etik yang dihubungkan dengan hukum positif. Kata jurisprudence berasal dari bahasa Latin, yaitu kata juris berarti hukum, dan prudens berarti kebijaksanaan. Seperti itu, mempelajari jurisprudence kita belajar dengan melampaui aturan-aturan (hukum positif). Kita mencoba belajar apakah nilainilai dari aturan diusahakan untuk ditanam untuk masyarakat.

\section{a. Etik Dari Keadilan.}

Keadilan adalah moral hukum sangat penting. Setiap sistem hukum, bukan persoalan baik atau jelek, telah menuntut untuk mempromosikan keadilan. Aliran hukum alam merumuskan hukum dalam hubungan dengan keadilan. Ide hukum alam mempunyai sejarah panjang, mencapai sedikitnya dari waktu kaum Stoic di jaman Yunani kuno. Pemikir hukum alam termasuk ahli filsafat jaman pertengahan seperti St. Thomas Aquinas, ahli hukum Inggris abad XIX Sir William Blackstone dan ahli filsafat penganut paham persamaan modern seperti John Rawls. Pemikir hukum alam seperti Blackstone mengatakan "suatu hukum tidak adil adalah bukan hukum dan harus tidak dipatuh". 
Yang sedang dikenali dengan berbagai teori hukum, tidak ada arti tunggal yang dapat diberikan kepada hukum alam. Di dalam suatu pengertian lebih luas, istilah yang digunakan untuk mengidentifikasi hukum yang ideal; di dalam suatu arti tambahan, adalah deskriptif untuk keikutsertaan orang sebagai makhluk rasional dalam menerapkan hukum yang eksternal bagi urusan manusia dengan mana ia membedakan antara baik dan buruk (Ervin H. Pollack, 1979: 27).

Hukum alam secara sederhana diartikan sebagai hukum yang dibangun berdasarkan alam. Dengan perkataan lain, hukum alam adalah hukum yang sesuai dengan alam. Menurut Blackstone, seorang penganjur hukum alam Inggris: "Hukum alam ini yang seusia dengan umat manusia dan yang diperintahkan oleh Tuhannya, tentu saja, merupakan kewajiban yang lebih tinggi dari lainnya. Itu mengikat semua yang ada di bumi, di semua negara, dan terus menerus, tidak ada hukum manusia manapun memiliki kebenaran jika berlawanan dengan hukum alam dan atas dua dasar hukum alam dan hukum perwahyuan digantungkan semua hukum manusia". Jadi sesuai dengan apa yang disampaikan oleh Blackstone, maka hukum yang dibuat oleh manusia dan perbuatan manusia tidak boleh bertentangan dengan hukum alam dan hukum perwahyuan (Peter Mahmud Marzuki, 2005: 4).

Salah satu contoh hukum alam (etik keadilan) adalah mendapat perlindungan. Mendapatkan perlindungan berhubungan dengan hak atas suatu pemeriksaan yang adil di depan hukum. Seperti itu, jika masyarakat bisnis melanggar Sherman Antitriust Act (UU anti monopoli) mengenai penentuan harga, mereka mempunyai suatu hak pe-meriksaan juri, dan kejahatan harus dibuktikan sebelum mereka dapat dihukum.

Pengadilan yang didasarkan "equity" dan ganti rugi yang layak juga memperlihatkan bagaimana etik keadilan mempengaruhi hukum positif. Kata "equity" berarti "kejujuran". Equity di pengadilan berasal dari Inggris ketika hukum di pengadilan menjadi tidak fleksibel dalam memperbaiki kesalahan-kesalahan.

Etik hukum mengenai keadilan terdapat badan untuk naik banding. Kelemahan utama pada etik keadilan bahwa ide keadilan seseorang seringkali tidak sama dengan yang lain, yang boleh dikatakan multiple-conscience problem (masalah suara hati orang banyak).

Dengan kata lain, kita semua boleh sepakat untuk jujur, tetapi kita boleh tidak sepakat mengenai apakah kejujuran diartikan dalam suatu persoalan hukum.

Di kebanyakan orang sepakat pada apakah keadilan adalah suatu kasus 
tertentu. Sebagai contoh, kebanyakan dari kita mungkin akan setuju bahwa hukum melarang pembunuhan adalah jujur dan adil.

Tetapi kita mungkin tidak sependapat pada hukuman untuk para pembunuh: beberapa percaya di dalam hukuman mati, dan beberapa tidak.

Hukum alam berhadapan dengan apakah hukum positif adalah hak, yang memimpin ke arah pertanyaan apakah hukum positif harus moral. Seorang sarjana yang telah mengerjakan pertanyaan ini adalah Lon Fuller. Fuller mengembangkan apa yang ia namakan "internal morality of law". Menurut Fuller, hukum positif harus ber-temu delapan tes untuk dipertimbangkan secara moral internal.

Delapan tes ini adalah : Prinsip harus dapat dipakai secara umum; Perintah undang-undang harus dikomunikasikan untuk mempengaruhi orang-orang; Prinsip hukum baru diumumkan, kecuali pada kesempatan luar biasa, harus ada harapan diterapkan; Standard tindakan dan tidak bertindak harus dinyatakan dengan jelas; Perintah yang kontradiksi harus dihindari untuk memastikan konsistensi; Sejak hukum dihubungkan dengan kapasitas manusia, tidak mungkin standard tindakan dan tidak bertindak harus tidak dikenakan; i tahun terakhir, beberapa otoritas sudah memandang stare decisis sebagai suatu halangan ke perubahan penting. Fuller, bagaimanapun, melihatnya sebagai bermanfaat dan diinginkan sudah menjadi sifatnya. Hukum sering berubah, ia membantah, cenderung untuk mempunyai suatu efek kurang baik pada orang yang tunduk kepada hukum yang diubah; Hukum harus manjur; seperti Fuller katakan, menunjukkan "sama dan sebangun" itu adalah, konsistensi antara norma-norma yang ditentukan dan tindakan mereka yang memaksakan (Ervin H. Pollack, 1979: 34-35).

Dengan demikian, internal morality of law sebagaimana yang dikemukakan oleh Lon Fuller menetapkan tes sebagai berikut: hukum harus berupa aturan; aturan-aturan harus dirumuskan secara resmi; aturan-aturan itu harus jelas; aturan-aturan sejarang mungkin berlaku surut; aturan-aturan harus tidak saling bertentangan; aturan-aturan harus tidak mewajibkan ketidakmungkinan; aturanaturan harus tidak sering berubah; di sini harus sama sebangun antara perilaku pejabat dan aturan.

Ahli filsafat abad $X X$ terkemuka bernama John Rawls mengembangkan beberapa ide hukum alam termasuk "original position". Menurut ide ini, jika masing-masing kita tidak mengetahui apakah posisi kita akan dimulai dari masyarakat, itu adalah, apakah kita akan 
kaya atau melarat, cerdas atau dungu, laki-laki atau perempuan, kulit putih atau kulit hitam, orang cacat atau tidak cacat, keturunan Asia atau Afrika atau Eropa, dan semua ciri-ciri lain yang mungkin- apakah kita akan menginginkan aturan itu? Rawls menyebut titik awal "original position". Itu adalah sangat menolong membenarkan hukum yang bersifat melindungi kelas orang siapa yang sudah secara kebiasaan mendiskriminasikan, perempuan dan minoritas rasial.

Prinsip keadilan inilah yang akan kita pilih jika kita belum mengetahui status sosial kita.

Orang-orang akan selalu bertindak sesuai kepentingannya sendiri dan kita tidak boleh membiarkan sesorang dengan kepentingannya memutuskan persoalannya sendiri. Satu-satunya cara yang dapat kita putuskan apakah keadilan itu, adalah membayangkan keadaan di mana kita tidak atau belum mempunyai kepentingan . Dalam keadaan ini tidak ada pilihan lain kecuali memutuskan dengan jujur (Achmad Ali, 1996: 91).

Rawls mengatakan bahwa seseorang yang rasional tanpa mengetahui bagaimana yang akan diterimanya dari masyarakat akan memilih prinsip keadilan yang "jujur". Justice as fairness, maksudnya prinsip keadilan mana yang palin "jujur" itulah yang harus dipedomani (Achmad Ali, 1996: 92).
Ahli filsafat Immanuel Kant, yang hidup di abad XVIII, yang mengusulkan dalam etik disebut "categorical imperative". Ide ini mempunyai akar hukum alam dan dikatakan kita perlu bertindak dengan cara yang sama akan menginginkan hukum itu.

Dengan kata lain, jika akan menginginkan hukum untuk melarang mencuri, kita sebagai individu perlu tidak mencuri.

Etik ini mengikuti prinsip yang sama sebagai aturan sangat bagus/baik, di mana dikatakan "Lakukan bagi orang yang lain seperti halnya anda dengan mereka lakukan bagi kamu".

Bagaimana perlakuan kategori memaksa dengan penipuan pajak? Akankah kamu ingin orang yang lain untuk menipu pajak mereka? Kebanyakan akan dikatakan bahwa wajib pajak perlu membayar semua yang mereka menurut hukum berhutang pemerintah ; dengan begitu kategori memaksa dikatakan masing-masing dari kita untuk menjadi jujur membayar pajak kita.

\section{B. Etik Dari Kekuasaan.}

Kekuasaan adalah etik dasar, Plato dalam bukunya The Republic, ketika sampai karakter Thrasymachus, ia mengatakan, "Keadilan adalah kehendak yang lebih kuat". Dengan cara lain menyatakan ide ini adalah "Kekuatan membuat hak (kebenaran)". Kekuasaan 
adalah esensial bagi hukum positif, sebab hukum positif menganggap bahwa keberadaan mereka yang memiliki kedudukan politis yang lebih kuat. Beberapa menyarankan bahwa kaum positivistis merupakan hanya pemuja kekuasaan.

Seseorang mendapatkan dan memelihara keunggulan politis menjadi kuat. Lagipula, kekuasaan dibutuhkan untuk menyediakan sanksi hukum positif. Kekuasaan dapat mengambil beberapa bentuk. Itu dapat kekuatan militer. Itu juga dapat bentuk kekuasaan ekonomi. Kemampuan untuk memotong anggaran seseorang atau manfaat atau pekerjaan seseorang adalah kekuasaan ekonomi. Kekuasaan dari suatu ide adalah, dalam banyak jalan, bentuk kekuasaan sangat kekal.

Kontrol sewa (Bruce D. Fisher dan Michael J. Phillips, 2001: 18) adalah suatu contoh jaman ini mengenai pengaruh kekuasaan etik ke dalam hukum positif. Banyak kotamadya di Amerika Serikat sudah lewat peraturan kontrol sewa yang menghentikan tuan-tuan tanah dari meningkatkan uang sewa lebih dari suatu jumlah yang ditetapkan masing-masing tahun. Kontrol ini merupakan hukum yang diperdebatkan yang memperlihatkan kekuatan etik penyewa dalam masyarakat kotamadya. Rakyat ini menggunakan kekuasaan pemilih dengan kekuatan dewan kota untuk mensahkan hukum kontrol sewa.

Seperti ketentuan merupakan secara politik popular sebab lebih banyak penyewa dari pada tuan tanah. Bagaimanapun, hukum kontrol sewa bisa jadi tidak bijaksana secara ekonomis. Sewa rumah baru akan tidak dibangun sebab tuan tanah akan tidak mendapatkan suatu pengembalian yang adil atas investasi mereka jika sewa tidak bisa diangkat untuk mencerminkan nilai/harga pasar.

Kontrol sewa benar-benar adalah suatu usaha sah untuk mencabut suatu hukum ekonomi, hukum permintaan dan penawaran, yang menetapkan harga. Kekuasaan etik dapat kontrol sewa secara legal, tetapi itu membahayakan persediaan persewaan perumahan masa depan. Apapun juga kebijaksanaan hukum kontrol sewa, mereka menggambarkan kekuasaan moral.

Tata tertib adalah suatu keuntungan yang utama bagi kekuasaan etik. Siapapun mempunyai kekuasaan dapat dengan kekerasan atau ancaman kekuatan membawa hukum dan tata tertib ke masyarakat.

Tata tertib ketika didasarkan pada ekonomi yang sehat akan membawa stabilitas jangka panjang, yang mendorong rakyat untuk berinvestasi dan komitmen sumber daya jangka panjang yang dikerjakan untuk perbaikan atau kemajuan 
masyarakat.

Investasi dalam per-tumbuhan, peralatan, dan rakyat (dengan pelatihan dan pendidikan) memajukan kualitas hidup masyarakat, tetapi kerangka jangka panjang adalah yang diperlukan merealisasi manfaat/ keuntungan dari investasi.

Rakyat dan perusahaan menghendaki untuk hanya penanaman modal di mana tata tertib dan stabilitas jangka panjang membuat keuntungan dari investasi. Keuntungan tidak mungkin direalisasikan di mana pemerintah secara konstan merubah aturan-aturannya. Tata tertib dan stabilitas ada karena kekuasaan etik.

Kekuasaan dapat disalahgunakan. Sebagai contoh, beberapa tahun yang lalu jawatan kereta api membebankan biaya muatan lebih tinggi kepada petani dan pelaku bisnis kecil dibanding mereka lakukan kepada konsumen besar tertentu.

Diskriminasi tarip yang tidak wajar ini mendorong untuk mengatur angkutan umum oleh Komisi Perdagangan Antar Negara Bagian. Penyalahgunaan kekuasaan lainnya dapat terjadi ketika pelaku usaha mengadakan atau mempromosikan orang-orang oleh karena ras, agama, seks, nasionalitas asal, atau umur. Suatu sistem penghargaan harus didasarkan pada produktivitas dan bukan atas pemberi kerja tidak menyukai, sebagai contoh : kulit hitam, dan perempuan (atau laki-laki).

\section{c. Etik dari Kebiasaan.}

Kebiasaan berhubungan dengan perilaku yang sudah berjalan lama. . Bagaimana rakyat bertindak dan melanjutkan tindakan adalah suatu etik yang mempengaruhi hukum positif. Savigny, penulis Jerman abad XIX, mengembangkan aliran historis. Dia mengatakan bahwa hukum positif mencerminkan kebiasaan yang sudah berjalan lama.

Banyak contoh yang menunjukkan bagaimana kebiasaan mempengaruhi hukum positif. Mempertimbangkan kehendak, dokumen seperti biasa kita gunakan untuk mengalihkan milik kita ketika kita mati. Kehendak mempunyai akibat hanya ketika seseorang meninggal dunia, tetapi pewaris tidak lagi dengan kita. Pada hakekatnya, kematian seseorang adalah menyuruh harus berbuat apa yang hidup dengan sumber daya seperti uang dan milik lain yang ditinggalkan.

Penyerahan hak milik oleh kehendak tersebut adalah kebiasaan yang sudah berjalan lama yang diakui oleh hukum positif. Kepemilikan milik privat ide bahwa seseorang dapat memiliki sebuah rumah atau mobil adalah kebiasaan yang sudah berjalan lama lainnya yang diakui 
oleh hukum positif.

Perumusan milik privat adakalanya berubah. Seperti suatu waktu, para budak merupakan hak milik yang dapat dijual dan yang dibeli. Barangkali suatu hari planet akan dipertimbangkan dimiliki oleh yang mampu memiliki.

Kontrak merupakan contoh bagaimana kebiasaan etik hukum dapat mempengaruhi hukum positif. Kontrak adalah kesepakatan sukarela antara individu-individu privat atau antara kelompok dan dapat dilaksanakan pada pengadilan.

Seorang lulusan siswa sepakat untuk bekerja dengan gaji per tahunnya membuat suatu kontrak. Kontrak semacam ini sudah lama dilaksanakan. Orang dapat merubah hidupnya dengan memasuki suatu kontrak (Bruce D. Fisher dan Michael J. Phillips, 2001: 20).

\section{d. Etik dari Norma Perilaku.}

Norma perilaku, yang berhubungan dengan bagaimana kebanyakan orang bertindak, merupakan etik lainnya yang mempengaruhi hukum positif. Norma sebagaimana kebiasaan, diterima kita tidak sudah berjalan lama, Eugen Ehrlich, aliran sosiologi hukum, merupakan perilaku sebagai etik, atau nilai.

Beberapa kelompok norma mengenai perilaku termasuk pelacuran seksual, keadaan mabuk, merokok ganja. kongkaling harga, dan yang memasang penawaran lebih tinggi, yang mana mempunyai suatu bayangan negatip. Tetapi norma mengenai perilaku tidak perlu dilarang dalam pengertian hukum positif. Sebagai contoh, semua jenis keadaan mabuk dan pelacuran seksual adalah tidak dilarang, walaupun sering keadaan mabuk umumnya, pengemudi yang mabuk, praktek seksual tertentu dilarang. Seperti itu, norma beberapa kelompok di masyarakat akan mem-pertanyakan pada alasan-alasan moralitas tidaklah perlu tidak sah.

Di sisi yang lain, merokok mariyuana, memasang penawaran yang tinggi, dan kongkalikong harga secara umum dilarang/ tidak sah menurut pengertian hukum positif sungguhpun aktivitas ini bisa menjadi norma perilaku bagi kawasan masyarakat tertentu. Seperti dapat kita lihat, norma bisa di bawah atau di atas hukum positif dan masih didasarkan pada yang ditanyakan berbagai nilai lain seperti kesehatan publik atau moralitas.

Etik perilaku merupakan suatu keuntungan karena itu bagaimana orang bertindak. Kita bisa memecahkan permasalahan dalam hukum yang ketinggalan dengan hanya mengubah hukum positif sedemikian sehingga setuju dengan perilaku sosial. 


\section{Jika hukum positif dan perilaku} sosial merupakan hal yang sama, penegakan hukum akan bersifat lebih murah dan lebih mudah.

Perilaku sosial dapat juga secara sosial tidak menyenangkan seperti membunuh, kejahatan dengan pembakaran, pemerkosaan, kongkalikong harga, meracuni, dan menjiplak pajak pendapatan seseorang.

Hukum positif akan membantu untuk memajukan masyarakat. Jika hukum positif dengan santai (longgar) mengijinkan perilaku terburuk, peradaban akan dibahayakan.

Orang-orang akan tidak lagi diselamatkan; mereka tidak akan percaya apa yang dikatakan orang lain; dan hak milik dapat dicuri dengan tidak takut hukuman. Hukum positif dan perilaku etik seringkali berselisih, karena hukum positif mendorong perilaku ideal. Norma perilaku mencoba untuk menurunkan ideal hukum positif terhadap penetapan yang diakui tidak realistik dengan standard yang tinggi (Bruce D. Fisher dan Michael J. Phillips, 2001: 22).

\section{e. Etik dari Peradaban.}

Peradaban merupakan suatu etik yang mempengaruhi hukum positif. Psikoanalisa Sigmund Freud mengatakan bahwa hukum memperlihatakan etik peradaban sebab menghalangi mencoba untuk stop) naluri seperti keinginan untuk dusta, menipu, dan mencuri. Semakin kita sebagai individu dan sebagai suatu masyarakat mencegah naluri dasar kita, semakin kita menjadi diberadabkan.

Hukum membantu kita untuk beradab karena pernyataan aturan-aturan menyatakan kepada kita apakah kita boleh atau tidak boleh melakukan.

Kita boleh tidak salah menyatakan jarak mil pada mobil kita ketika kita menjualnya sebab ini bisa jadi penipuan. Kita boleh tidak menipu partner bisnis kita sebab akan melanggar kewajiban kepercayaan kita, kewajiban kesetiaan kita. Kita boleh tidak membuang bahan kimia yang belum dinetralisir ke dalam pembuangan sebab ini akan melanggar undang-undang.

Kita boleh tidak mengemudikan mobil di atas batas kecepatan. Kita boleh tidak gagal atas menyerahkan bagian di luar pendapatan kepada pemerintah sebagai pajak. Bidang ketenagakerjaan, kita boleh tidak membedakan atas dasar umur.

Di sini dan hukum lainnya mencegah naluri dasar kita. Bagaimanapun, mereka melakukan tidak sama sekali membatasi kita, sebab beberapa aktivitas kita dikerjakan dengan nikmat tidak ditimbulkan dari naluri dasar kita, sebagai contoh: bekerja,belajar dan membantu 
lainnya.

Keuntungan etik peradaban adalah secara praktis bebas dari kejahatan. Di bawah peradaban, rakyat, pelaku usaha, dan pemerintah di bawah kontrol dan yang diatur, dan semua orang mendapatkan suatu rasa kehidupan baik yang bebas.

Etik peradaban juga mempunyai kerugian atau biaya. Peradaban menyebabkan frustasi, dan orang-orang mengarahkan permusuhan dan serangan dalam batin mereka, yang dapat menyebabkan borok, serangan jantung, tekanan darah tinggi, alergi, dan sakit kejiwaan (Bruce D. Fisher dan Michael J. Phillips, 2001: 22).

\section{f. Etik dari Kemanfaatan.}

Yuris dan ahli filsafat Inggris Jeremy Bentham untuk mempromosikan kebutuhan "kebahagiaan terbesar untuk sejumlah orang terbesar", dikenal sebagai "ethic of utilitarianism".

Ide dasar utilitarianisme adalah untuk mem-perbanyak kebahagiaan masyarakat. Kebahagiaan terdapat arti kemanfaatan (kepuasan). Ekonomi modern didasarkan pada ide kemanfaatan Bentham karena ahli ekonomi mengatakan bahwa sumber daya di masyarakat terbatas dan oleh karena itu kita perlu menggunakannya secara maksimum untuk kemanfaatan masyarakat. Karenanya, seseorang yang menggunakan etik kemanfaatan sebagai pedomannya untuk perilaku layak mencoba untuk memaksimumkan kemanfaatan.

Mereka secara konstan mempertimbangkan satu tindakan melawan orang lain, akibatnya, menjaga keseimbangan alternatif untuk melihat hasil kebaikan yang terbesar untuk jumlah yang terbesar.

Etik kemanfaatan seringkali merefleksi dalam hukum postifif. Pembuat hukum (pengadilan atau badan pembuat undang-undang) sering menyeimbangkan persaingan argumentasi atau tuntutan untuk memutuskan apa yang merupakan aturan yang layak untuk perilaku masyarakat. Penyeimbangan adalah suatu bentuk mengenai alasan memberi manfaat. Sebagai contoh, Andaikata $O$ memiliki suatu cincin intan. $\mathrm{T}$, seorang pencuri, mencuri cincin itu dan menjualnya untuk $\mathrm{G}$, suatu pembeli beritikad baik untuk harganya, yang percaya bahwa T memiliki cincin itu. O kemudiannya mendengar bahwa $G$ mempunyai cincin dan menggugat $\mathrm{G}$ untuk mendapatkan kembali cincinnya ( $T$ tidak bisa ditemukan) $G$ akan membantah bahwa dia membeli cincin itu dengan beritikad baik untuk harganya tanpa memperhatikan bahwa $T$ tidak memiliki itu. G akan juga membantah bahwa orang-orang harus bisa membeli 
barang-barang dari orang yang nampak untuk pemilikinya, yang mempromosikan nilai kebebasan berkontrak dan mendorong bisnis, di sisi lain, akan membantah bahwa dia mempunyai suatu hak milik ( memiliki) cincin, yang seorang pencuri harus tidak mampu bertanggung jawab dengan penjualan kepada pembeli yang beritikad baik.

Hakim dalam kasus ini harus memilih antara nilai-nilai milik (mempromosikan stabilitas kepemilikan hak milik) dan mempromosikan bisnis (dengan memberi harapan kepada orang-orang untuk masuk kontrak) (Bruce D. Fisher dan Michael J. Phillips, 2001: 25).

Utilitarianisme diperhalus dengan memasukkan 2 ide yang berbeda : rule utilitarianism dan act utilitarianism. Rule utilitarianism mencoba untuk memaksimumkan kebahagiaan masyarakat dengan aturan (hukum positif). Act utilitarianism mencoba untuk memaksimumkan kemanfaatan bahkan jika diartikan merusakkan hukum positif. Perbedaan antara rule dan act utilitarianism dapat dimengerti dengan menetapkan penggunaan obat terlarang. Asumsi hukum positif melarang penggunaan obat kecuali jika seseorang mempunyai suatu persetujuan dokter.

Suatu rule utilitarian tidak menggunakan seperti obat tanpa suatu persetujuan dokter bahkan jika melakukan juga untuk sementara membuat rasanya lebih baik. Suatu act utilitarian, di sisi lain, akan menggunakan obat terlarang jika membuatnya lebih diperlonggar.

Pertimbangan ini diikuti karena act utilitarian mengabaikan hukum positif ketika mereka mencoba untuk memaksimumkan kemanfaatan. Suatu rule utilitarian yang menginginkan untuk mengurangi kekuatan dengan penuh semangat untuk 20 menit. Penggunaan tidak melanggar manapun hukum positif dan itu menghasilkan "endorphin betas", suatu jenis penawar sakit alami, yang secara alami dan menurut hukum mengurangi. Dengan begitu ketika kamu melihat orang yang berjalan, kamu hampir bisa dipastikan sedang mengamati aturan bermanfaat (Bruce D. Fisher dan Michael J. Phillips, 2001: 25).

\section{Kelemahan etik kemanfaatan:}

Mempertimbangkan persaingan tuntutan menyebabkan orang-orang untuk berpikir dan mempertimbangkan alternatif sebelum mereka bertindak, yang mana dengan jelas diinginkan.

Ketika pengadilan atau badan pembuat undang-undang membuat suatu hukum dan menggunakan etik kemanfaatan sebagai pemandu, yang mempertimbangkan nilai (dalam pandangan pembuat undang-undang) akan berlaku; 
Bumi menghadapi suatu kenyataan: sumber daya langka dan lebih banyak orang-orang seluruh penjuru dunia kurang untuk meningkatkan taraf hidup mereka. Utilitarian menempatkan suatu nilai yang tinggi dalam memaksimalkan kemanfaatn sosial secara total. Karena itu, utilitarian memainkan suatu peranan penting dalam tempat hukum positif hari ini, aturan seharusnya ditulis untuk ke-manfaatan sosial maksimum yang diberikan pada sumber daya langka yang meningkat;

Ini menekankan pasar sebagai cara untuk menjatah sumber daya langka. Pasar-beda dari pemerintah-jadilah lebih efisien dibanding kebanyakan birokrasi. Pasar sekarang ini dilihat sebagai mekanisme untuk penyerahan pelayanan kesehatan, daripada pengaturan pemerintah, memberi kebutuhan akan efisiensi di area penting ini;

\section{Utilitarianisme menyediakan} suatu cara untuk membatasi suatu cara masuk akal hukum positif itu. Hari ini hukum dan ekonomi menggerakan suatu alat yang analitis penting dalam memikirkan hukum positif. Pertimbangan adalah bahwa orang-orang menuntut hak, tetapi gagal untuk melihat bahwa permintaan seperti itu sudah berhubungan biaya-biaya (Bruce D. Fisher dan Michael J. Phillips, 2001: 25).

\section{Kelemahan etik dari kemanfaatan antara lain:}

Utilitarisme memberikan pembuat keputusan (hakim, atau badan pembuat undang-undang, sebagai contoh) terlalu banyak kekuasaan, tetapi tuntutan bersaing selalu ada ketika keputusan dibuat. Hakim dapat merosotkan pendapatnya untuk kebaikan satu tuntutan di atas yang lain oleh pembuatan argumentasi yang sangat kuat bagi tuntutan yang disukai dan hanya argumentasi yang lemah bagi tuntunan yang bersaing yang tidak disukai.

Bahwa sering melibatkan suatu analisis pasar, yang menggunakan kurva permintaan dan penawaran. Kurva permintaan dan penawaran adalah kumpulan, mewakili keajaiban " rata-rata" konsumen dan "rata-rata" para penyalur. Pada hakekatnya, dengan berkonsentrasi pada rata-rata, semua orang dikurangi menjadi suatu kloning semua orang selain itu. Apakah semua orang, sesungguhnya, serupa? Tidak, tetapi dengan perlakukan semua orang sebagai serupa, analisis pasar menyangkal ciri khas.

Bahwa konsumen adalah yang berkuasa, orang yang sangat penting di masyarakat. Apakah yang bisa bersalah dengan perlakukan konsumen sebagai penting? Jawaban adalah bahwa beberapa konsumen tidak membedakan. 
Asumsi bahwa semua berbagai hal mempunyai suatu nilai dolar ((Bruce D. Fisher dan Michael J. Phillips, 2001: 26).

Etik berhubungan dengan suatu perilaku yang diinginkan. Menentukan apakah perilaku yang diinginkan dalam situasi yang diambil tergantung pada nilai-nilai apa seseorang mengikuti. Nilai yang direkomendasikan untuk pedoman adalah hukum positif. IImu hukum (jurisprudence) adalah studi nilai-nilai mengenai hukum dan sistem hukum.

Aliran ilmu hukum hadir dengan perbedaan nilai untuk mempertimbangkan apakah hukum positif cocok dengan perilaku etik. Tulisan ini menguji etik dari keadilan. Hukum alam adalah apakah setiap orang berpikir jujur, adil atau hak sungguhpun ini boleh berbeda bagi hukum positif.

Di dalam mempertimbangkan keadilan, persoalan moralitas yang dibahas. "Internal morality of law" dari Lon Fuller meletakkan 8 karakteristik moral pada hukum positif. "Original position" dari John Rawls adalah suatu tipe hukum alam. "Categorical imperative" dari Kant mengungkapkan suatu konsep hukum alam sama dengan "aturan yang baik".

Keadilan (hukum alam) sering, tetapi tidak selalu, sepakat dengan hukum positif. Kekuasaan adalah suatu etik yang berbentuk hukum positif. Kecuali jika kekuasaan mendukung hukum positif, hukum positif akan tidak bertahan. Kebiasaan (aliran historis) adalah suatu nilai atau etik yang berhubungan dengan perilaku yang berulang dalam periode waktu yang panjang. Banyak hukum positif seperti hukum kontrak dan men-ciptakan hak milik privat, mencerminkan kebiasaan. Di Jerman, Savigny, mendukung etik kebiasaan.

Eugen Ehrlich, aliran sosiologi hukum, menekankan etik norma perilaku. Bagaimana tindakan orang rata-rata adalah suatu etik. Etik peradaban berhubungan dengan pencegahan naluri dasar kita, seperti keinginan untuk mencuri. Sigmund Freud mendukung ide ini.

\section{Daftar Pustaka}

Ali, Ahmad, Menguak Tabir Hukum (suatu tinjauan filosofis dan sosiologis), Chandra Pratama, Jakarta, 1996.

Fisher, Bruce D. dan Michael J. Phillips, The Legal, Ethical, dan Regulatory Environment of Business, West Legal Studies in Business, South-Western College Publishing, Mason, 2001.

Hampstead, Lord Lloyd and M.D.A. Freeman, Introduction to Jurisprudence, Stevens \& Sons Ltd., London, 1985.

Marzuki, Peter Mahmud, Aliran-aliran Dalam IImu Hukum (The Schools of Jurisprudence), Makalah Pelatihan IImu Hukum Fakultas Hukum Universitas Airlangga tanggal 4 Agustus 2005. 
Paton, G.W., A Textbook of Jurisprudence, Oxford University Press, London, 1974.
Pollack, Ervin H., Jurisprudence (Principles and Applications), Ohio University Press, Columbus, 1979. 